\title{
Hope Fostering Among the Yoruba Speaking People of Nigeria: The Use of Proverbs, Cognomen, Prayers and Names
}

\author{
C. O. Ajila
}

\section{INTRODUCTION}

Proverbs, according to Makinde (1987), contain the observations, knowledge and wisdom of our forefathers who condensed what they would have put down in writing into short witty phrases. It is a pleasure indeed to see how Yoruba proverbs blend harmoniously with the point they treat, thus driving the point home so vividly that the audience enters full into their feelings. Proverbs are the seasoned. Philosophical thought they are, they reveal and explain the beliefs and also the psychology of the Yoruba.

In Yoruba society no one can be considered educated or qualified to take part in communal discussions unless he is able to quote the proverbs relevant to each situation (Delano, 1983; Daramola and Jeje, 1975).

"Owe l'esin oro, bi oro ba sonu, owe ni a fi nwa a"

Translation: A proverb is the 'horse' or vehicle' of words, if a word is lost, proverb to find it. Proverbs are the means of searching out the truth; when the truth is missing, proverbs are the vehicles through which they are discovered.

The apt usage of an appropriate proverb is of primary importance in daily interaction (Sannoh, 1986).

Human communication is the process whereby we convey ideas, opinions, attitudes, feelings sentiments, beliefs or impressions to others. It is a means by which we send and receive information. Communication touches every sphere of human activity. It informs all of man's actions because it is occasioned by his needs to interact with his fellow man. It manifests itself in symbolic verbal forms. Alston (1962:40) described the effectiveness of communication as a helping tool when he wrote that:

The very act of attempting to communi-cate with another person

about matters of personal concern may lead him toward greater

clarity and psychological expansion, discrimination and synthesis.

Every facet of our life from birth to death is affected by our ability to relate to other people, which in turn are affected by how well we know ourselves. No human being has ever been born "alone". We are born into human relationships. This part of our personal identity is formed by these relationships. We experience ourselves through the responses of others. When two people are communicating, they are sending and receiving messages simultaneously.

Viewed from a psychological perspective, a "Communication action" cannot be suitably described without answering the following questions; who said what, by what channel, to whom and with what effect?

The above outline of communication emphasizes its importance in human interaction. Amongst the Yorubas, the role of communication in fostering hope cannot be overemphasized. The Yorubas have a very rich tradition and culture which is depicted in language. Thus, Yoruba ideas are often woven into expressions, which give form and character to their existence.

\section{Yoruba Language and its Speakers}

Yoruba is spoken as a first language in virtually the whole area of the old Western Nigeria particularly in the Oyo, Ondo, Ogun, Osun, Lagos and Ekiti States. It is also spoken in Kwara State and as a s '

econd language by many Isekiris. The exact varieties of the language are not known, but the most well known and documented is the standard variety referred to as Standard Yoruba (Akinkugbe, 1978). This is the variety used as kind of Lingua franca among speakers of the other varieties of the language. Other known varieties of the language include those of Ijesa, Oyo, Ondo, Ekiti, Owo, Ikale, Ijebu, Egba, Akoko etc.

\section{The Concept of Hope}

Hope is a sufficient sustainer of a happy life. It is distinct from faith and charity because it is directed exclusively toward the future. It is 
fervent desire and confident expectation. Hope can arise under the conditions.

According to Marvel (1962), the cognitive activity of hoping emerges under the condition of tragedy or captivity. For Marcel and Pruyser (1991), it is when a person feels caught or when a person is visited by a difficult set back that he can hope. Hope can therefore be understood as a problem instigated adaptive behaviour. We feel hopeful mainly in the fact of obstacles to our needs and plans.

The other condition under which hope can arise is when there is a goal to be attained or a life project to be achieved (Synder, 1993, 1994a, 1994b). Under this second condition, hoping essentially is understood as a positive expectancy that a target we have set for ourselves will be met. These two conditions according to Nwoye (1991) should be seen as complementary rather than contradictory to one another.

In Marcel's view, before genuine hoping can be said to be present, there must be a little amount of incertitude or doubt entertained by the hoper. As a corollary to Marcel's view, Price (1969) states that hope lives in the intermediate region between two opposed convictions. The person who hopes must not be absolutely sure that the event will not happen, but neither must he is absolutely sure that it will. For Bloch (1971), to hope means to live in dreams and fantasies of the future, or to strive for a desirable future. Hope is therefore, a source of motivation and creative initiative in human life.

In his attempt to define hope in more concrete terms, for example, Snyder (1994) states that hope is a cognitive set involving beliefs in ones' capabilities to produce workable routes to goals (the pathway component) as well as the self-related beliefs about initiating and sustaining movement toward these goals (the agentic component). According to Snyder and his associates, hope is linked to action toward a goal through hard work and organization, and thus must be seen as an adaptive and goaldirected response in human beings. In making reference to what happens when we hope, they presented a conviction, which shows that he who hopes properly has greater advantage in coping with life over those who are deficient in hoping. In this context, their position is that when we hope genuinely we tend to appraise our goals positively, and when blockages occur to these goals we tend to perceive them as being the normal inevitability of life, and typically are not unduly disturbed by such situational stressors.

\section{Fostering Hope Among the Yorubas}

\section{Use of Proverbs}

Here are some of the proverb used by the Yorubas in fostering hope:

(i) "Aja ti o pa ikun l'oni le pa oya lola, nitorina ki a ma binu pa aja"

Translation: The dog which kills a deaf squirrel today may kill a can rat tomorrow, so we must not be angry and kill the dog. The squirrel is worth little, but the rat is much prized.

Use: He who has succeeded in a small way today should be encouraged possibly he will achieve greater things in the future.

(ii) "Ki iburuburu ko ma ku enikan mo ni, eni ti yio ku ni a o mo”.

Translation: Things are never so bad that there remains nobody at our side; but we do not know who it is, will remain

Use: Comment to encourage someone facing so many problems and difficulties that someone will turn up some time to give a helping hand. (iii) "Pipe ni yio pe akololo yio pe baba" Translation: However long it will be the stammerer will call "baba" (father). The word, "ba" is the first syllable in Yoruba language. It is also the first effort to express a syllable by many who stammer, and by children learning to speak. Use: However long a time a thing may take, with patience the goal will ultimately be achieved.

(iv) "Asese won ologbo ni "jiya, bi o ba pe titi a to eku pa je".

Translation: A man who has just attained a position of responsibility difficult to Understand, but after a while he will master the situation.

(v) Eni ti o ba nsise ki ise ole, bi ori ba tun ni se, a ki iti boro

Translation: One who is working hard should continue to do so, if one is lucky in life, one will not easily fail (this is said to console people who, though they are working hard, do not succeed in life. Success depends upon luck or destiny.

(vi) Bi a ngun iyan ninu ewe, ti a nse obe ninu epo pa, eniti yio yo, yio yo.

Translation: If one pounded yam is prepared on leaves, if soup is cooked in a ground nut husk, 
the person who is destined to be full will be full. Use: Do not be despondent because circumstances change. In most situations while some may lose, others may gain. One man's failure may be another man's opportunity.

Note: The translations of the proverbs follow the Yoruba wording fairly closely, except where the difference of idiom between the two language is so great as to make a literal translation meaningless. The English comments are paraphrases not translations of the Yoruba.

\section{An example of How Proverb could be Used to Foster Hope}

Miss T had her secondary school education in the village. She was sent by her father to go and stay with her uncle in Lagos so that she can retake her school certificate examination. While in Lagos she was also struggling to gain admission into the University. Her uncle registered her in a continuing education centre, but in spite of her effort to have a good stay with her uncle, life was made comfortable for her by her uncle's wife. She was treated like a slave by her (the wife of Miss T's uncle). Neighbours and close friends did not like how the wife of Miss T's uncle was treating her. One day when one of the family friends (a woman) was consoling Miss $\mathrm{T}$ after she had been maltreated, said: "ki iku ma pa eni ti nda ni loro, ki orisa ma je ki nkanse eni ti nse ni n'ika, bi o pe titi ori eni a da ni lare" - (May death not kill the man who tortures us; may the gods protect the man who ill-treats us. However long it may be our destiny will give us victory).

Miss T kept on enduring and working hard. She could not report her uncle's wife to anybody. In fact if she reports to her uncle, he will not listen and she did not want to go back to the village without achieving anything. She then sat for her school certificate examination and made a good pass. That same year, she got admission into a Nigerian university. That was how she left her uncle's house and gained her independence.

People who are being ill treated should have faith in their future, if they persevere.

\section{Use of Cognomen}

Abraham (1958) defines cognomen "Oriki" as an attributive name expressing what the child is or what it is hoped that it will become. In a male, the "oriki" connotes something heroic, while in a female, it connotes endearment.

The term "Oriki" according to Akiwowo (1983) and Adeboye (1973) refers to the praise chants or recitation of achievements of an individual's or group ancestry, and similar oral works which are intended to make full a person's image of himself, or to provide a great amount of historical or biographical information to a person or group in order to create a full sense of self-awareness or identity in that person or that group. According to the traditional bards (Abimbola 1975), the purpose of the Oriki is to preserve a record of the past and to spur listeners by recitals to greater achievements in emulation of their ancestors. Two distinguishing characteri-stics of the oriki is its singularity and the sonorous language in which it is always delivered.

(i) The Cognomen for "Ibeji" - twins goes thus:

"Ejire okin ara isokun omo edun gbalaja ori igi

omo oto tii je ni leele

okan mba bi

eji lo wole to mi

o so alakisa do nigba aso

o sotosi doloro..."

Translation: My adorned twins, I thought I would have just one child, but alas, two came. You made a poor parent rich, you brought fortune to the family...

The Yorubas see twins as children that should be treated specially because of the circumstance of their birth. The Yorubas also believe that when a family has twins, things will change for better, for twins will bring good fortune to the family.

(ii) The Cognomen for members of my family

(The Ajilas family)

Omo Ajila bi Orangun

Omo Akin, Omo ekun

Omo igi rabata lokun

Omo agbe di agbe je

Omo olope bimo jingini

Omo a mo oke owo sooti .......

Translation: The brave child, the generous one. You are noted for your Gene-rosity and open handedness.

Members of the Ajila family historically were noted for their generosity, open handedness and 
bravery. The ancestors were very helpful to their neighbours. The cognomen thus became a way of reminding the past and to spur them to greater achievements.

\section{A Personal Example of How the Recitation of Cognomen Could Foster Hope}

Once upon a time, I went for the wedding engagement of a friend in my hometown. While we were there some traditional drummers were invited to come and entertain guests. During the ceremony the time came when friends of the celebrant were called to come and dance with them. While we were dancing, the drummer started reciting my cognomen. I was elated. I was happy and had to give the drummer more money than I would have done if he (the drummer) had not recited my cognomen.

\section{Use of Prayers}

Hope is fostered among the Yorubas through prayers. This goes to show that some prayer points are offered to help in lifting the hearer up e.g. "E o ko wa pe o" (May you live long to guide us).

"E ko ni rin ni ojo ti ebi n pa ona" (May

your trips always be accident

free) "ale a san e" (May your old age be full of joy).

At the death of a relative, the bereaved members of the family can be consoled with expression such as "Olorun a wo awon omo ti $o$ fi sile"

Translation: God will protect the children that the dead person has left behind.

When a person is going on a journey the Yorubas have expression such as "Oko a refo". Translation: You will arrive safely at your destination. "Ogun ko ni fi eran wa yi yepe" Translation: You will not have accident on the way.

When a person has just married, the Yorubas have expressions such as:

"Ehin iyawo ko ni mo eni"

Translation: May the wife give birth to a baby within a short time. All the above expressions are prayers meant to foster hope in the person to whom they are directed.

Here is a case of someone who hoped that a difficult situation could be handled with prayer.

Mrs. XY received her retirement letter while she least expected it. She was worried. She did not known what to do and where to start from since she has not planned for the retirement. She started praying and fasting hoping that through prayers better doors could be opened. She was comforted with the words of God and believing that God would take adequate care of her future.

\section{Names}

When a child is born he or she can possibly have three sets of names

1. Family name

2. First name

3. Natural name (when a child is born in a way peculiar to certain children born under similar circumstances, they are called by specific names e.g.

Aina/Ojo - name for children with cord round their neck

Taiwo and Kehinde - Twins

\section{Ajayi - Name for Children Who at Birth Turn} Their Faces Downwards

Ilori - name for children born without previous menstruation.

Dada - a child with a curly hair in the head. Other names apart from those above are also given with specific meanings.

A child is not given just any name for the fun of it. The parents generally will consider first, the circumstances of birth and then the family name in line with the history of the family. Thus the Yorubas will say "Ile ni a nwo ki a to so omo l'oruko".

Translation: Before we give a child a name, we have to consider the family.

A child from a king's family will bear "Ade" or

"Oye" plus other names

"Ade" means crown

"Oye" means title

Adebiyi - the crown has given birth to this Oyekunbi - the family is replete with title.

A child from the family of warriors will bear "Akin plus other names.

Akin" means fearless

Akinbowale - the warrior has returned home.

A child from the family of worshipers of Ogun (the god of iron) will bear "Ogun" plus other names. 
Ogunseye - Ogun (the god of iron) has done me honour.

As all these names are called, the bearers' sense of identity is aroused and will always work towards living up to what is expected of people that bear such names.

\section{METHODOLOGY}

Primary data used in this study were collected directly from all the respondents through a questionnaire (designed by the researcher). Subjects for this study were 222 male and female (youths, adults and elders) drawn purposively from two towns (Ile-Ife and Ado-Ekiti) in the South West of Nigeria. The two hypotheses generated for the study were subjected to appropriate statistical analyses using t-test statistic to find out whether there was a significant difference in the subjects' responses according to gender and marital status.

\section{Hypothesis 1}

"There is no significant difference between male and female Yoruba speaking people in their use of words that foster hope".

Data obtained from 222 respondents was analysed using t-test statistic. The results (see table 1 below) show a mean score of 38.7 for the males and a mean of 42.6 for the female subjects. T-test comparison $(\mathrm{t}=1.13)$ showed a non-significant difference between males and females at 0.05 levels. Since t-calculated is less than table-value the result is not significant. This result therefore supported the hypothesis, which predicted that there would be no significant difference due to gender in the subject use of words that foster hope.

Table 1: Mean scores and t-test analysis of male and female respondents on the use of words that foster hope

\begin{tabular}{lrrrrrr}
\hline Gender & $N$ & $X$ & $S D$ & $d f$ & $t c$ & $P$ \\
\hline Male & 142 & 38.7 & 8.56 & & & \\
Female & 80 & 42.6 & 10.84 & 219 & 1.13 & $<0.05(\mathrm{NS})^{*}$ \\
\hline
\end{tabular}

*Not Significant

\section{Hypothesis 2}

"Married and single Yoruba speaking people will not exhibit differences in their use of words that foster hope".

Data obtained from 100 married and 122 single respondents was analysed using t-test independent means. The results (see Table 2 below) show a mean score of 27.36 for married and a mean of 26.0 for single subjects. T-test comparison showed a non-significant difference between married and single subjects at 0.05 levels and df of 210.

Since t-calculated is less than the tabled value, the result is not significant. This result therefore supported the hypothesis, which stated that there would be no significant difference due to marital status in the subjects' use of words that foster hope.

\section{DISCUSSION AND IMPLICATION OF FINDINGS}

From the result obtained, the first hypothesis was accepted $\mathrm{t}-\mathrm{cal}=1.13, \mathrm{tv}=1.960)$. The result indicated that there is no statistically significant difference between male and female speakers of Yoruba language in their use of words that foster hope. This shows that there is no gender difference among the Yorubas in the use of words that foster hope. This finding is supported by Soetan's (1986) and Ajila's (1998) studies. They found that gender has no relationship to the mastery of one's native language. An individual's mastery and understanding of a language will depend on his or her exposure to the language. The second hypothesis, which states that married and single Yoruba speaking people will not exhibit differences in their use of words that foster hope, was also supported. The reason for the absence of difference might be due to the fact that marital status has nothing to do with the exposure that individuals have to their native language.

On the basis of the findings, the following are some of the conclusions drawn:

- The findings of the study have shown that in spite of the people's exposure to Western culture, the Yorubas are adequately equipped for the challenges of the future with use of thought-provoking, hope-fostering words like proverbs and cognomen.

- Non-use of those words that foster hope can lead to distortion and falsification of thought processes. According to Makinde (1987), a traditional counselor who employs proverbs empathizes with his clients. 
Table 2: Mean scores and t-test analysis of married and single respondents on the use of words that foster hope

\begin{tabular}{lrrrrrr}
\hline $\begin{array}{l}\text { Marital } \\
\text { Status }\end{array}$ & $N$ & $X$ & $S D$ & $D f$ & $T c$ & $P$ \\
\hline Married & 100 & 27.36 & 1.78 & & & \\
Single & 122 & 26.0 & 1.98 & 219 & 1.80 & $<0.05(\mathrm{NS})^{*}$
\end{tabular}

*Not Significant

- The use of hope-fostering words like natural names and cognomen give a sense of identity and the possibility of spurring the listener to greater achievement.

- Beneficial changes can be produced in a disturbed family unit through the use of hope-fostering words. Careful consideration must be given to family history while naming a child.

- The use of hope-fostering words can help improve self worth and a sense of accomplishment.

An example of hope fostering expression that can help improve self-worth:

Mura si ise ore mi, ise ni a fi ndi eni giga.

Ti a ko ba ri eni fi ehin ti bi ole ni a nri

Ti a ko ba ri eni gbekele a tera mo ise eni....

Translation: Work hard my friend; hard work surely takes one to the top, if you have no helper, you look like a lazy person, if no sponsor, then be hardworking. Your mother may be rich, your father with horses in tethers, if you depended squarely on them, you are done for. What you don't suffer for, you don't treasure; what you sweat for, it's worth you know.

KEYWORD Communication. Gender. Marifal Status. Mental Health.

ABSTRACT This paper examines the role of communication in fostering hope among the Yoruba speaking people in Nigeria. Specifically, the paper focuses attention on the use of proverbs, cognomen, prayers and names in hope fostering. Data for the study came mainly from questionnaire survey. For purposes of the study, 222 male and female subjects were drawn from two states (Osun and Ekiti) in the South Western part of Nigeria. The data collected were subjected to appropriate statistical analysis using the t-test. Results show no gender and marital status differences on the usefulness of those words that foster hope in a Yoruba speaking individual. The implications of all these for the mental health of various family members are discussed.

\section{REFERENCES}

Abimbola, W.: Tradition, selections from papers presented at the seminar of Yoruba Oral Tradition, Poetry in music, Dance and Drama., Department of African Languages and Literature, Obafemi Awolowo University, Ile-Ife (1975).

Adeboye, B.: Awon Oriki Orile: Yoruba Classics, Iwe Kinni, Collins Publishers, Ibadan (1973).

Abraham, R.C. Dictionary of Modern Yoruba. Hodder and Stoughton, London (1978).

Ajila, C.O.: A psychological investigation into the Honorific Systm in Yoruba Language. The Ethnographer, Port Harcourt (1998)

Akinkugbe, O.O.: A Comparative Phonology of Yoruba Dialects, Unpublished Ph.D Thesis. Department of Linguistics, University of Ibadan, Ibadan (1978).

Akiwowo, A.: Understanding interpretative Sociology in the light of the Oriki of Orunmila. Journal of Cultures and Ideas: An African Journal of Transdisciplinary Studies, 1 (1), 39-157 (1983).

Alston, B. : Bibliotherapy and Psychotherapy. Library Trends, 12(2):40 (1962).

Ddaramola, O., and JEJE, A.: Awon Asa ati Orisa Ile Yoruba. Onibon Oje Press and Book Industries (Nig.) Limited. Ibadan (1975).

Makinde, O.: Cultural Resources for integrated counseling in Nigeria. The Nigerian Journal of Guidance and Counselling, 3(1-2): 73-85 (1987).

Marcel, G.: Homo Viator. Harper and Row. New York (1962).

Nwoye, A.: "Hope Theory as a foundation for Elip-zotherapy." Paper Presented at the XIth World Congress of Family Therapy, held in Akron, U.S.A. (1999).

Ojerinde, D.: Educational Tests and Measurements. Codat Audio-Visual Services, Ibadab (1986).

Pruyser, P.W. Phenomenology and Dynamics of Hoping. Journal of the Study of Religion, 1(2):231-245 (1991).

Sannoh, B.O.: Yoruba Child Psychology. In : E.B. Wilson (Ed.). Psychology and Society. Nigerian Psychological Association Publication (1986).

Shyder, C.R.: Hope and Optimism. Encyclopedia of Human Behaviour, vol. 2, p. 234-541 (1994a).

Snyder, C.R.: The Psycholoy of Hope : You can get There from Here. Free Press, New York (1994b).

Author's Address : Dr. Chris O. Ajila, Department of Psychology, Obafemi Awolowo University, Ile-ife, Nigeria.

E-mail: cajila@oauife.edu.ng 